IZA DP No. 8380

Social Mobility and the Importance of Networks: Evidence for Britain

Oscar Marcenaro Gutierrez

John Micklewright

Anna Vignoles

August 2014 


\title{
Social Mobility and the Importance of Networks: Evidence for Britain
}

\author{
Oscar Marcenaro Gutierrez \\ University of Malaga
}

\author{
John Micklewright \\ Institute of Education, London \\ and IZA
}

Anna Vignoles

University of Cambridge

and IZA

Discussion Paper No. 8380
August 2014

IZA

P.O. Box 7240

53072 Bonn

Germany

Phone: +49-228-3894-0

Fax: +49-228-3894-180

E-mail: iza@iza.org

\begin{abstract}
Any opinions expressed here are those of the author(s) and not those of IZA. Research published in this series may include views on policy, but the institute itself takes no institutional policy positions. The IZA research network is committed to the IZA Guiding Principles of Research Integrity.

The Institute for the Study of Labor (IZA) in Bonn is a local and virtual international research center and a place of communication between science, politics and business. IZA is an independent nonprofit organization supported by Deutsche Post Foundation. The center is associated with the University of Bonn and offers a stimulating research environment through its international network, workshops and conferences, data service, project support, research visits and doctoral program. IZA engages in (i) original and internationally competitive research in all fields of labor economics, (ii) development of policy concepts, and (iii) dissemination of research results and concepts to the interested public.
\end{abstract}

IZA Discussion Papers often represent preliminary work and are circulated to encourage discussion. Citation of such a paper should account for its provisional character. A revised version may be available directly from the author. 
IZA Discussion Paper No. 8380

August 2014

\section{ABSTRACT \\ Social Mobility and the Importance of Networks: Evidence for Britain}

Greater levels of social mobility are widely seen as desirable on grounds of both equity and efficiency. Debate on social mobility in Britain and elsewhere has recently focused on specific factors that might hinder social mobility, including the role of internships and similar employment opportunities that parents can sometimes secure for their children. We address the help that parents give their children in the job market using data from the new age 42 wave of the 1970 British Cohort Study. We consider help given to people from all family backgrounds and not just to graduates and those in higher level occupations who have tended to be the focus in the debate in Britain. Specifically, our data measure whether respondents had ever had help to get a job from (i) parents and (ii) other relatives and friends and the form of that help. We first assess the extent and type of help. We then determine whether people from higher socio-economic status families are more or less likely to have such help and whether the help is associated with higher wages and higher occupations. Our paper provides insight into whether the strong link between parental socio-economic background and the individual's own economic success can be explained in part by the parents assisting their children to get jobs. We find parental help to have a strong social gradient. But we are unable to identify a clear link between any particular type of help advice, help through contacts etc. - and individuals' wages or occupations.

JEL Classification: J62

Keywords: $\quad$ social mobility, networks, family, wages

Corresponding author:

John Micklewright

Department of Quantitative Social Science

Institute of Education

University of London

20 Bedford Way

London WC1H OAL

United Kingdom

E-mail: J.Micklewright@ioe.ac.uk

\footnotetext{
* We are grateful to the Centre for Longitudinal Studies, Institute of Education, London for their support for this work.
} 


\section{Introduction}

The desire to achieve a socially mobile society, in which every person can succeed regardless of who their parents are, is the professed aim of every major party in the UK (Cabinet Office, 2011). Despite this, levels of intergenerational social mobility remain relatively low (Ermisch, Jantti \& Smeeding 2012). As a consequence, there is a lot of interest in whether help in the job market from families and their networks strengthens the intergenerational transmission of advantage and hence is a brake on social mobility e.g. Cabinet Office $(2009,2012)$ and Macmillan, Tyler and Vignoles (2013). There is interest in the issue in other countries too e.g. Bingley, Corak and Westergård-Nielsen (2011). Much of the discussion in the UK focuses on the upper end of the socio-economic distribution. For example, there are concerns about access to the professions, especially of graduates, and over the role of unpaid or poorly paid internships that affluent parents can sometimes secure for their children. Viewed in this light, personal connections and social networks provide the brake on mobility described and the only issue is how big a brake this represents.

But connections and networks may operate at all levels in the labour market so that their effects on economic advantage and social mobility may be both more widespread and less obvious than at first sight. In contrast to much of the literature for the UK, we investigate the help given by parents, other relatives, and friends to people who work in the full range of occupations and who come from all family backgrounds. We draw on data from the newly available age 42 wave of the 1970 British Cohort Study (BCS70), which contains information on help received in the job market for a sample of over 9,000 individuals. We relate this help to the data collected on parental circumstances when the cohort members were aged 10 . In doing so, we provide new evidence on the extent of social mobility in Britain, comparing the socio-economic status of the 42 year olds measured in 2012-13 to that of their parents over 30 years earlier in 1980, updating analyses such as that by Bukodi and Goldthorpe (2011). We also provide insight into the extent to which the use of connections and networks can explain the strength of the relationship between parental socio-economic background and an individual's own success in the labour market.

The paper contributes to the existing literature in two ways. First, as has been said, it provides more recent evidence on the extent of intergenerational social mobility for a cohort born in 1970 and adds to the controversial debate about the extent of social mobility in the UK (Blanden, Goodman, Gregg, \& Machin, 2004; Blanden \& Machin, 2004; Blanden, Gregg \& Mcmillan, 2013; Goldthorpe \& Mills, 2008; Gorard, 2008; Erikson \& Goldthorpe, 2010; Goldthorpe, 2013).

Second, the paper draws on the literature on barriers to access to professional careers (Langlands, 2005; Macmillan, 2009; Macmillan, Tyler \& Vignoles, 2013; Sutton Trust, 2005, 2006). Some studies within this literature have suggested that the use of networks is a possible mechanism by which social advantage is reproduced in the labour market. The empirical evidence on the role of networks is limited but shows that they are generally effective ways in which individuals can generate job offers, with positive impacts on their labour market success (Loury, 1977, 2006; Holzer, 1988). As networks are a form of social capital it is also clear that access to networks is likely to be socially graded (Coleman, 1990). Individuals will have different types of networks depending on their family situation, their past work experience and the current industry that they work in (Ioannides \& Loury, 
2004; Fernandez \& Castilla, 2001; Marsden and Gorman, 2001). To this extent, networks can potentially reinforce social and economic advantage.

Within this broader literature key papers have examined a specific form of network, closely related to the focus of this paper, namely the support that parents give their children in securing employment. For example, Bingley, Corak and Westergård-Nielsen (2011) consider the extent to which children are employed in the same organisations as their parents and find that wealthier fathers are more likely to have sons who have worked for the same employer, implying a social grading to this form of assistance. Corak and Piraino (2010) suggest that in Canada around $70 \%$ of the sons of the wealthiest fathers have worked in the same firm as their father at some point (see also Kramarz and Skans, 2006). Unfortunately our data do not have specific information on whether the individual has worked in the same firm as their father or mother but it does contain information on the types of help parents have provided. The types of help vary enormously. For instance, the data include information on whether the respondent received advice from his or her parents. Clearly one might argue that it is the role of all parents to provide advice and that this may not constitute something that is socially undesirable. By contrast, if a parent provides an internship for their child this may be problematic from a social mobility perspective. In our discussion of the data below we consider carefully the importance of how help from parents and friends is measured and hence the meaning of our findings.

Section 2 explains the BCS70 data that we use, contrasting this with other types of data that have or could be used to investigate the issues. Section 3 begins by documenting the extent and type of help received in the job market that is recorded in the data before analysing the association of this help with parental socio-economic status. In Section 4 we focus on help from parents. We report first on individuals' own subjective valuation of the help they have received before then using regression models to obtain an objective valuation in terms of wages and occupations. Section 5 concludes.

\section{The BCS70 data}

The data we use are drawn from the age 42 sweep of BCS70, conducted in 2012-13. Some 9,800 cohort members responded, which represents about $60 \%$ of the original cohort. Respondents were interviewed face-to-face and the questions put to them included four on help in the job market from parents, other relatives and friends. First, respondents were asked:

'Have your parents ever done any of the things on this card to help you to get any job you have ever had? Please include internships and placements, even if unpaid.'

Provided advice

Helped with application forms

Acted as a reference

Recommended me to an employer that they work for or had worked for

Recommended me to an employer that they did not work for

Directly employed me

Helped me find a job through people that they know

Other (specify)

No - none of these 
All those types of help that were indicated were coded separately. Respondents were next asked:

'In your judgement, how much has the help [of all types] that you received from your parents to get a job contributed towards your current occupation or career?'1

A lot

A little

Or not at all?

Unfortunately the second question does not enable us to link the respondent's answer to the specific help provided. So if a parent provided many forms of help to their offspring, the second question can only provide us with an indication of whether the help provided overall was considered useful or not.

Cohort members were then asked the same two questions in respect of help from 'your friends or other relatives'. We make less use of the data resulting from these questions. The definition of a friend is less clear-cut than a parent and, in part associated with this, there is likely to be a greater problem of recall e.g. a friend who gave help 20 years ago by providing some advice could now be long-forgotten. The problem of recall is no doubt there for both sources of help however.

In both cases, namely parents and friends and other relatives, the 'help' may not always in fact be help in the sense of having a potentially positive impact. Help could limit an individual's chances of moving up a career ladder by encouraging restricted aspirations. The questions are not nuanced enough to deduce whether respondents would have reported receiving help if they perceived it to have limited their ambitions, although we do have their own valuation of the value of all the help they have received. In any case, respondents may not realise that the 'help' they received actually limited their options, though we test in our modelling whether the help they received is correlated with their subsequent economic success.

There are a number of additional limitations to the data. The questions on help cover the entire working lives to date of persons who entered the job market up to a quarter century prior to interview. First, there is the issue of recall bias. Those who received parental help and were successful in their endeavours may be more (or perhaps less) likely to remember that they received help. Second, even with complete measurement, we need to recognise that the data are very different to those that have been used in other studies of social networks, contacts and social mobility. For example, the data drawn on by Macmillan, Tyler and Vignoles (2013) from the Destinations of Leavers from Higher Education (DLHE) survey, which contain information on parental help, refer only to very recent graduates. Our BCS70 data refer to a much wider group of individuals, which is an advantage. But as a record of past help over 25 years to people now in mid-career they do not necessarily provide insight into what parents, other relatives and friends are currently doing in the UK job market to help young people, whether graduates or those who have never been to university. The nature of the current job market, including its structure of occupations, certainly differs from that first faced by the BCS70 respondents in the late 1980s. The much

\footnotetext{
${ }^{1}$ Asked only to those reporting any help. The question was not asked in respect of each type of help: the subjective valuation of 'the help that you received' therefore refers to all help of all types.
} 
greater prominence of white-collar internships is just one example. The decline in blue-collar jobs in manufacturing is another.

The BCS70 data also refer to help of various types that respondents' report, which contrasts with the information from the administrative registers used by Bingley, Corak and Westergård-Nielsen (2011) and by Corak (2010), that simply recorded whether parents and children had ever worked for the same employer. This administrative data does not suffer from recall bias and has the advantage of measuring something specific that we might say is clearly going to act as a break on social mobility. If children secure jobs in their parents' firms, this is a mechanism which would undoubtedly encourage intergenerational social immobility and reinforce, by definition, the status quo. By contrast our questions ask about a range of help that might be provided by parents, other relatives and friends, not all of which may be considered deleterious to society. As has been described, we have data on whether the individual received advice from his or her parents or had their help with application forms. These are perhaps desirable things for parents to do. The extent to which they are done and the impact that such assistance provides may be socially graded, in a similar way to other parent activities, such as reading aloud with your child. However, this does not mean that we want to discourage parents from doing these things. When we interpret our results we pay close attention to the meaning of the measures of help that we are using, and we largely focus on those that are arguably ways in which families may in some sense secure "unfair" advantage for their children, recognising that this is a highly contested notion. In particular we focus on specific measures which indicate the potential use of social or economic advantage to secure particular employment opportunities for a child, namely whether or not the parent provided the individual with help to get a job through the use of their contacts, and whether or not the parent recommended their child to a current or previous employer for a job.

Our strategy is to relate the help that BCS70 members report to their family socioeconomic status (SES) before they entered the job market. By contrast, current SES is best seen as an outcome variable that the help may have furthered. To do this, we link the age 42 data to the data collected from parents in the 1980s when the cohort members were aged 10. (The mean age of parents when the cohort members were aged 10 was 34 for fathers and 31 for mothers). The age 10 data provide information on two measures of SES: family income and parental socio-economic group (for the latter we take father's group or the mother's if the father's is missing). All the analysis that follows is conducted on the sample of individuals present in both the age 42 sweep and the earlier age 10 sweep. This means that we lose 753 cases of the total 9,841 in the age 42 sweep, giving us an analysis sample of 9,078 individuals. The cases lost include those not responding at age 42 , immigrants to the UK since the age of 10 and individuals not present in the age 10 survey who then responded to subsequent sweeps. ${ }^{2}$

Table 1 describes the social mobility that help in the labour market may - or may not - partly explain. It shows the distribution of cohort members' socio-economic group (SEG) at age 42 by parents' SEG at age 10. Reading across a row gives the percentages of children from the age 10 parental SEG who are in each SEG at age 42. The SEG classifications at the two ages are not identical despite the categories having the same names, but they are

\footnotetext{
${ }^{2}$ Immigrants who arrived between 1970 and 1980 may also not be present in our chosen sample as they were not all identified for the age 10 sweep. We are grateful to Matthew Brown for this information.
} 
sufficiently indicative for our purposes. ${ }^{3}$ SEG is missing for $9 \%$ of the sample at age 10 and $16 \%$ at age 42 (the latter includes a small number classified as 'other') but we include these groups in the table as an additional row and column respectively.

Table 1. Parental SEG when cohort member aged 10 and own SEG at age 42 (row \%)

\begin{tabular}{l|cccccccc|c}
\multicolumn{1}{c}{$\begin{array}{l}\text { Age 10 parental } \\
\text { SEG }\end{array}$} & Unskilled & $\begin{array}{c}\text { Partly } \\
\text { Skilled }\end{array}$ & $\begin{array}{c}\text { Skilled- } \\
\text { Manual }\end{array}$ & $\begin{array}{c}\text { Skilled } \\
\text { N-Man }\end{array}$ & $\begin{array}{c}\text { Manage- } \\
\text { Tech }\end{array}$ & Prof. & Missing & Total & (All) \\
\hline Unskilled & 3.5 & 15.3 & 14.7 & 16.6 & 22.6 & 1.9 & 25.5 & 100.0 & $(3.5)$ \\
Partly Skilled & 2.1 & 13.5 & 17.3 & 17.1 & 31.2 & 2.2 & 16.7 & 100.0 & $(11.6)$ \\
Skilled Manual & 2.2 & 10.8 & 18.0 & 16.6 & 32.3 & 3.7 & 16.5 & 100.0 & $(36.8)$ \\
Sk. Non-Man. & 1.1 & 8.0 & 11.0 & 18.2 & 41.8 & 5.8 & 14.0 & 100.0 & $(10.3)$ \\
Manage-Tech. & 0.8 & 7.6 & 10.5 & 14.1 & 46.4 & 7.4 & 13.2 & 100.0 & $(23.3)$ \\
Professional & 0.4 & 4.8 & 4.4 & 12.0 & 52.3 & 15.8 & 10.2 & 100.0 & $(5.7)$ \\
Missing & 2.6 & 12.4 & 14.9 & 11.8 & 35.2 & 4.1 & 18.9 & 100.0 & $(8.8)$ \\
\hline (All) & $(1.7)$ & $(10.1)$ & $(14.3)$ & $(15.5)$ & $(37.5)$ & $(5.3)$ & $(15.7)$ & $(100.0)$ & $(100.0)$
\end{tabular}

Notes. $\mathrm{n}=9078$. The SEG categories are V, IV, IIIM, IIINM, II and I and refer to the Registrar General's Social Groups classification. The parental SEG is the father's occupation and if missing the mother's.

The figures in brackets in the final row and column show the distribution for the full sample at each age. These show that on average, there has been a clear upwards shift in the occupational levels of the children relative to those of their parents, reflecting the decline in blue collar jobs as observed earlier. For example there are many fewer cohort members in the 'skilled manual' group at age 42 than at age 10 (14\% compared to 37\%), while the opposite is true for the managerial-technical group where there has been a big rise in its importance (from $23 \%$ to $38 \%$ ). The percentages in the interior of the table show the transition probabilities. For example, $68 \%$ of children with professional parents at age 10 were either in the professional group themselves at age 42 or were in the managerialtechnical group. The figures for children with unskilled, partly-skilled and skilled-manual parents reaching the professional or managerial technical level were only $25 \%, 33 \%$ and $36 \%$ respectively. The Transition probabilities differ somewhat for men and women. For example, while $75 \%$ of men with professional parents were in the professional/technical group themselves at age 42 , this is the case for only $62 \%$ of women (not shown). ${ }^{4}$

Blanden et al (2013) used the same data set to examine the relationship between age 10 parental SEG and the individual's own SEG at age 33, some ten years earlier than our data. Although the SEG categories are not completely consistent due to differences in the classification of socio-economic groups, Blanden et al. (2013) found that $70 \%$ of children with professional parents at age 10 (category 7 , Table 4) were either in the professional or the lower managerial groups by age 33 (categories 6 and 7, Table 4). Thus when we consider these individuals further on in their careers at age 42 , we continue to find that the

\footnotetext{
${ }^{3}$ The age 10 classification refers to the 1970 version of the Registrar General's Social Groups classification and the age 42 classification refers the 1990 version.

${ }^{4}$ The t-statistic for the test of the difference is 3.2. Note however that all transition probabilities to higher level occupations are lower for women on account of the higher percentage with SEG missing at age $42: 20 \%$ compared to $11 \%$ for men.
} 
vast majority of children from professional backgrounds also achieve higher level occupations.

\section{Who gets help in the job market?}

Table 2 shows the percentages of our sample who report receiving help in the job market at some point in their working lives by type of help received as measured by BCS70, distinguishing between (i) parents and (ii) other relatives and friends. Just over half of men $(55 \%)$ report receiving help from parents and just under half of women (47\%). And about a half of both sexes (48\%) report help from other relatives and friends. Parental and relative/friend help tend to go together (or at least their reporting tends to) although the overlap is far from complete: about $30 \%$ of the sample - a bit more for women and a bit less for men - report neither source of help. This figure indicates that the use of family and other networks is not ubiquitous, as proposed earlier, at least as measured in the BCS70 data.

Table 2. Prevalence of help from parents and friends (cell \%)

a) Men

\begin{tabular}{|l|c|c|c|}
\hline \multirow{2}{*}{ Help from parents } & \multicolumn{3}{|c|}{ Help from other relatives or friends } \\
\cline { 2 - 4 } & No & Yes & Total \\
\hline No & 28.5 & 16.2 & 44.7 \\
\hline Yes & 23.2 & 32.1 & 55.3 \\
\hline Total & 51.7 & 48.3 & 100.0 \\
\hline
\end{tabular}

b) Women

\begin{tabular}{|l|c|c|c|}
\hline \multirow{2}{*}{ Help from parents } & \multicolumn{3}{|c|}{ Help from other relatives or friends } \\
\cline { 2 - 4 } & No & Yes & Total \\
\hline No & 33.2 & 19.6 & 52.8 \\
\hline Yes & 18.7 & 28.5 & 47.2 \\
\hline Total & 51.9 & 48.1 & 100.0 \\
\hline
\end{tabular}

Note. $n=4356$ (men) and 4722 (women)

What types of help did people receive? As we have noted, some forms of help are potentially more worrying from a social mobility perspective than others. Table 3 is restricted to those individuals who do report help of some sort - the figures show the percentage receiving each type of help for the sub-sample of all those receiving any help. The percentages sum to more than 100 as more than one type can be received. Advice is easily the most common source of help from parents, reported by over two-thirds of men and nearly three-quarters of women. The second most common assistance from parents is help with application forms, which again features more prominently for women. Next comes help through contacts, reported by $29 \%$ of men getting any help from parents and $21 \%$ of women. This is a form of parental support that we have argued should be seen in a different light to 
just having advice. Given that about half of respondents report parental help of any type, these figures imply that about 1 in 6 of all men and 1 in 10 of all women say they have been helped by parents in this way. Recommendation to a former or current employer, which we have argued is another type of help that is particularly important to consider, is next in importance: $19 \%$ of men reporting any help and $15 \%$ of women.

Table 3. Percent receiving each type of help among those receiving any help

\begin{tabular}{|l|c|c|c|c|}
\hline \multirow{2}{*}{ Type of help: } & \multicolumn{2}{|c|}{ Men } & \multicolumn{2}{c|}{ Women } \\
\cline { 2 - 5 } & parents & $\begin{array}{c}\text { Other } \\
\text { relatives/ } \\
\text { friends }\end{array}$ & parents & $\begin{array}{c}\text { Other } \\
\text { relatives/ } \\
\text { friends }\end{array}$ \\
\hline Provided advice & 67.9 & 40.6 & 73.0 & 42.1 \\
\hline Help with application form & 31.9 & 14.8 & 38.8 & 25.3 \\
\hline Acted as a referee & 12.6 & 35.2 & 7.8 & 42.6 \\
\hline Recommended to current/former employer & 18.9 & 37.0 & 14.6 & 27.4 \\
\hline Recommended to another employer & 9.7 & 13.4 & 5.3 & 7.7 \\
\hline Directly employed me & 16.7 & 14.0 & 10.4 & 8.4 \\
\hline Helped find job through contacts & 29.3 & 25.4 & 20.6 & 15.8 \\
\hline Financial & 0.5 & 0.3 & 0.2 & 0.1 \\
\hline Other & 0.8 & 0.6 & 1.1 & 0.8 \\
\hline Missing & 0.5 & 0.6 & 0.5 & 0.4 \\
\hline
\end{tabular}

Notes. Sample sizes in the four columns are 2408, 2105, 2229, and 2270. Percentages do not sum to 100 as more than one type of help may have been received. The base for the calculation in each case is all persons receiving any type of help.

The pattern is rather different for help from other relatives and friends. Advice is still a very prominent source of help but is reported by less than half of both men and women. Acting as a referee is almost as common as advice for men and equally so for women. Recommendation to a current or former employer is reported by about 1 in 3 people getting any help, much more than for help from parents, which reflects the fact that work and social life intersect for many people.

We now show how the probability of receiving help varies with parental SES. We first consider income. Figure 1 shows the percentages of the sample receiving parental help and help from other relatives and friends of any kind by categories of total net family income in $£$ per week at age $10 .^{5}$ Information on income is missing for $13.4 \%$ of the sample. Those missing income information are similar, in terms of the help they receive, to those with complete income data ${ }^{6}$. The income groups are very unequal in size - the intervals $£ 50-99$, $£ 100-149$, and $£ 150-199$ contain about $80 \%$ of the sample.

\footnotetext{
${ }^{5}$ This is a measure of household earned and unearned income, consisting of the combined gross income of mother and father. Child benefits were not included but other sources of earned and unearned income were.

${ }^{6}$ Parental help was received in $51.3 \%$ of cases where age 10 income is missing and help from other relatives and friends in $52.1 \%$.
} 
Figure 1. Percent of cohort members receiving help from parents and from other relatives or friends by family income at age 10

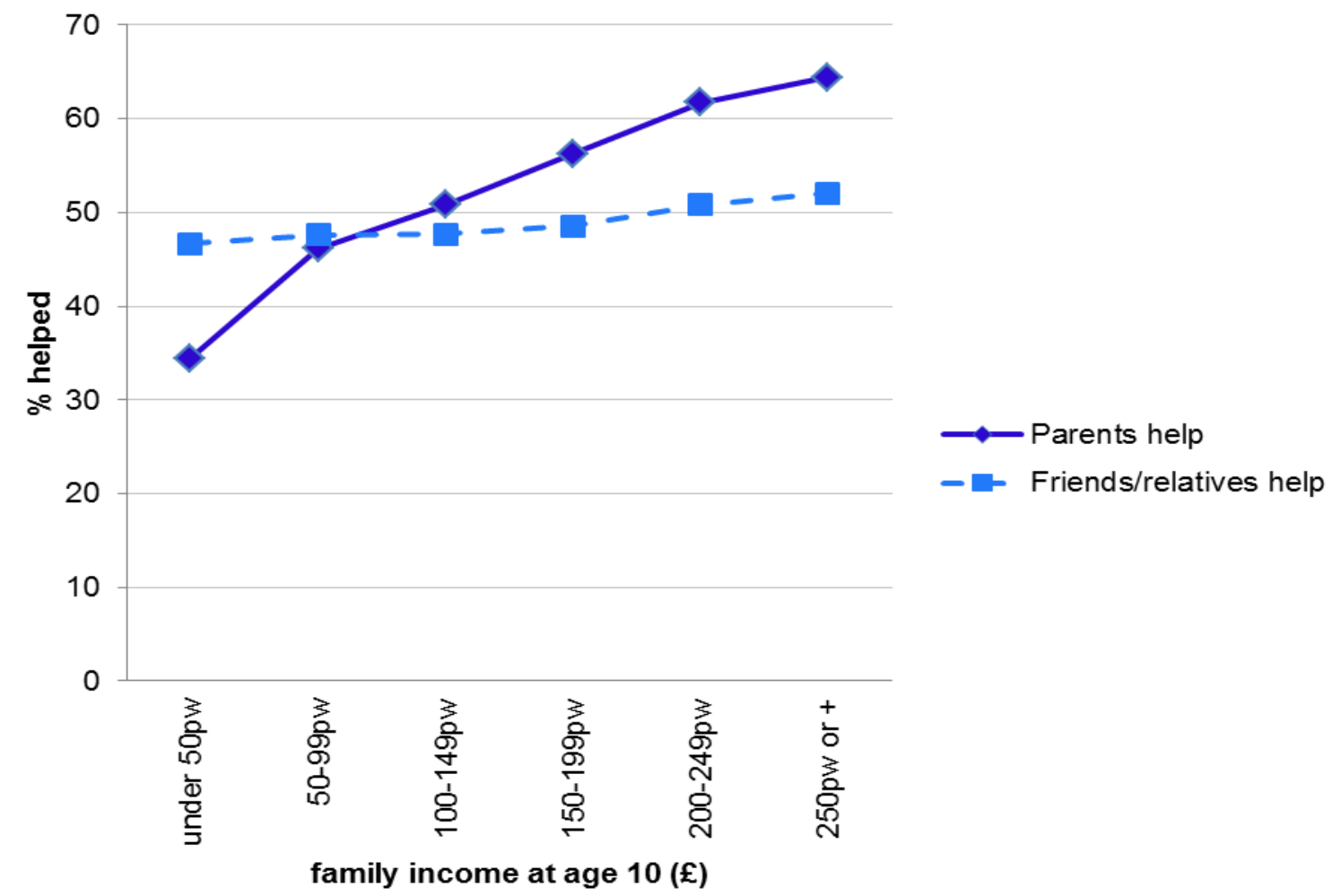

Note. $\mathrm{n}=7862$

The probability of reporting help from parents rises substantially with income, from $34 \%$ in the bottom group of under $£ 50$ to $64 \%$ in the top group of $£ 250$ or more (each of these two groups contains about $6 \%$ of the sample). ${ }^{7}$ But there is a much flatter relationship for help from other relatives and friends with only a modest rise across the income distribution from $47 \%$ to $52 \%$.

Figure 2 shows results for our other measure of SES at age 10, parental socioeconomic group. A similar pattern holds to that for income, at least in terms of the sign of the SES gradient. There is a higher probability of receiving parental help in higher SEGs: it is $40 \%$ and $44 \%$ in the bottom two groups and $61 \%$ and $60 \%$ in the top two groups. But the probability of receiving help from other relatives and friends differs little between different occupational groups. Broadly speaking therefore, the picture obtained of the social gradient in both types of help is robust to the SES measure used. There is little difference in the pattern by gender with either measure.

\footnotetext{
${ }^{7}$ We have combined two intervals, under $£ 35$ and $£ 35-£ 49$, containing 122 cases and 360 cases respectively, to form the bottom group shown in the graph. The percentages receiving parental help differ sharply in these two groups but the imprecision in the estimate for the under $£ 35$ interval due to the small sample size led us to combine the groups as described.
} 
Figure 2. Percent of cohort members receiving help from parents and from other relatives or friends by parental SEG at age 10



parental SEG at age 10

Note. $\mathrm{n}=8280$

We now probe the social gradient for different types of help, restricting the analysis to help from parents as we believe it is likely to be better measured. We take parental SEG as our measure of family background but the findings are similar using family income. Table 4 shows the percentages reporting (i) advice, (ii) help with application forms, (iii) recommendation by a parent to a current or former employer, and (iv) help to find a job through a parental contact ('people that they know'). In contrast to Table 3, we now take the base for the calculations as all individuals in the parental SEG group concerned, whether they had any help or not: the figures show the percentage of all individuals in each group receiving that particular kind of help.

The results for advice are not surprising - this is the most common form of help from parents and, since it is also socially graded, it is a major driver in the SEG gradient that we have already seen in Figure 2. A quarter of the sample with unskilled parents reports advice from them, rising to a half for those with at least one professional parent. The probability of help with applications - the second most frequent form of parental assistance - also rises significantly with parental SEG. But it is notable that neither help in finding a job through contacts nor a recommendation to a current or former employer appears strongly associated with higher parental SEG. Broadly speaking, these forms of parental help seem equally 
common for people from different family backgrounds (there is just a small increase in the prevalence of use of contacts in managerial and professional families.)

Table 4. Percent of cohort members receiving help from parents of various types by parental SEG at age 10

\begin{tabular}{|l|c|c|c|c|}
\hline Parental SEG at age 10: & $\begin{array}{c}\text { Provided } \\
\text { advice }\end{array}$ & $\begin{array}{c}\text { Relp with } \\
\text { applications }\end{array}$ & $\begin{array}{c}\text { Recommend } \\
\text { to } \\
\text { current/ } \\
\text { former } \\
\text { employer }\end{array}$ & $\begin{array}{c}\text { Helped find } \\
\text { job through } \\
\text { contacts }\end{array}$ \\
\hline Unskilled & 24.8 & 12.7 & 6.7 & 11.8 \\
\hline Partly Skilled & 29.2 & 14.8 & 8.7 & 11.7 \\
\hline Skilled Manual & 31.2 & 14.8 & 8.8 & 12.2 \\
\hline Skilled Non-Manual & 39.9 & 21.5 & 8.7 & 12.3 \\
\hline Managerial-technical & 45.6 & 23.3 & 9.1 & 15.6 \\
\hline Professional & 48.8 & 26.6 & 7.1 & 14.3 \\
\hline
\end{tabular}

Notes. $\mathrm{n}=9078$. The values for the group with parental SEG missing are $30.7 \%, 13.9 \%, 7.8 \%$ and $9.4 \%$.

\section{What is the value of the help received from parents?}

Thus far we have simply considered the relationship between whether a person received help from their parents and their socio-economic background. We have shown that some but not all types of help provided by parents are socially graded. Of course even if all parents provide help to their children in a number of different ways, such help may not be equally valuable. Parents who are wealthier and have higher occupational status may be more able to provide the kind of help that leads to greater economic success. Whilst we do have information on whether the individuals themselves think the help was useful, this is not necessarily a good way to determine whether more advantaged parents provide the kind of help that leads to greater labour market success. An individual may have found their parents' help useful, perhaps in securing them a job, but it does not necessarily mean that this enabled them to make as much progress career wise as the help provided by wealthier parents. To judge the average effectiveness of the help provided by parents we estimate the impact of receiving that help on individuals' eventual labour market success at age 42, measured by wages and by occupational group.

We start however, by first considering the subjective valuation by the cohort member: the question on 'how much has the help to get a job contributed towards your current occupation or career'. As discussed in Section 2, the information generated from this question is limited by the fact that although we know whether the help provided was deemed useful, we cannot be sure exactly what type of help the individual was referring to. Table 5 shows the distribution of answers for those receiving any help by parental SEG at age 10. Broadly speaking, a bit more than a third of the sample view the help they received as having contributed not at all, a third think it contributed a little, and a bit less than a third see 
it as having been contributed a lot. The figures vary little by parental SEG: for example the percentage responding 'a lot' is $27 \%$ for those with partly skilled manual parents and $25 \%$ for those with professional parents.

Table 5. Own valuation of parental help by parental SEG at age $\mathbf{1 0}$ for all receiving any help (row \%)

\begin{tabular}{|l|c|c|c|c|}
\hline & \multicolumn{3}{|c|}{$\begin{array}{c}\text { Contribution of help to current } \\
\text { occupation or career }\end{array}$} & \\
\hline Parental SEG age 10 & None & A little & A lot & Total \\
\hline Unskilled & 36.8 & 25.6 & 37.6 & 100.0 \\
\hline Partly Skilled & 38.2 & 34.1 & 27.7 & 100.0 \\
\hline Skilled Manual & 37.7 & 30.5 & 31.8 & 100.0 \\
\hline Skilled Non-Manual & 37.2 & 35.0 & 27.8 & 100.0 \\
\hline Managerial-technical & 35.3 & 33.4 & 31.3 & 100.0 \\
\hline Professional & 38.9 & 36.0 & 25.1 & 100.0 \\
\hline Missing & 39.3 & 28.5 & 32.2 & 100.0 \\
\hline All & 37.2 & 32.3 & 30.5 & 100.0 \\
\hline
\end{tabular}

Notes. $\mathrm{n}=9078$

We now attempt to provide an objective valuation of the help provided. We estimate a wage regression, where the dependent variable is log of the gross monthly wage of the individual at age 42 and we relate this to an individual's socio-economic background, their years of education and their ability, as measured by maths test score at age 10 (standardised to have a mean of zero and standard deviation of one). To ensure a parsimonious specification, to ease interpretation and to avoid multi-colinearity between different measures of parental socio-economic background, we only include parental SEG at age 10 (results are robust to using parental income instead). We estimate the model separately for men and women. To this standard wage equation we then add terms indicating whether the individual received a particular kind of help from their parent. We interpret a positive significant coefficient on the help variables as indicative that the help provided had some labour market value. Any impact of parental SEG on wages that comes through the child achieving more years in education or having higher ability at age 10 (for a discussion of the mechanisms see e.g. Haveman \& Wolfe, 1995) will be picked up by the coefficients on those variables - we wish to measure only the impact of parental help in the labour market over and above that coming through education and ability. We interpret any significant reduction in the magnitude of the coefficients on the parental SEG variables once the network variables are included as indicative evidence that parental networks and help are one route through which individuals from more socio-economically advantaged backgrounds secure labour market advantage. We then consider whether similar findings hold when we use SEG at 42 as opposed to earnings as the dependent variable. This latter model also provides a rather larger sample size - we have 6,131 observations in the wage regressions but 7,657 in the models of SEG. 
Our work comes with caveats. First, we cannot interpret the coefficient on parental help as a causal parameter. Clearly it may be that individuals who are likely to do well in the labour market are also more likely to secure assistance from their parents. We therefore note that our results are associative only. Second, our estimates will suffer from bias if the help variables are measured with error, either due to recall bias or because they are not posed in such a way as to obtain accurate information about how the individual was assisted by his or her parents. We cannot determine the direction of the bias since it may not be classical measurement error if some types of individuals are more or less likely to misreport the help they received e.g. those who come from advantaged backgrounds or those who secure very good jobs.

Table 6 reports the results from the wage regression for men and Table 7 for women. The model in column 1 includes background variables only, including parental SEG. Column 2 reports on a model including just a single dummy variable indicating that any help from parents was received. Column 3 adds additional controls to distinguish the type of help reported.

The results for men in column 1 show a substantial association of wages with parental SEG, conditional on years of education and ability at age 10: having a professional parent is associated with wages at age 42 that are about $28 \%$ higher on average than if the individual had a skilled manual parent (the excluded base category). A managerial-technical parent is associated with an average $19 \%$ wage premium and a skilled non-manual parent $17 \%$. By contrast, for women Table 7 generally shows no statistically significant association of wages with parental SEG except that women with professional parents have earnings that are on average $19 \%$ higher than women with a skilled manual parent, conditional on the education and ability measures which themselves have estimated coefficients that are notably larger than for the men (by between 20 and 60\%). For women, the association of parental occupation at age 10 and offspring wages at age 42 appears largely accounted for by the measures of years of education and ability.

The dummy variable in column 2 in each table is statistically insignificant - we find no evidence for either men or women of higher average wages for those reporting parental help of any type. Column 3 then assess whether there are any additional wage premia associated with the different types of help. This specification seeks to determine whether, even if there is no overall impact from receiving help, perhaps some specific types of help might be associated with greater labour market success. Again however, we find no significant impact of any type of help on wages at age 42 for men or for women. 
Table 6. The relationship between parental help and age $\mathbf{4 2}$ log gross monthly wages: males

\begin{tabular}{|c|c|c|c|}
\hline & Spec. I & Spec. II & Spec. III \\
\hline \multirow[t]{2}{*}{ Years of education } & $0.046^{\star \star \star}$ & $0.046^{\star * *}$ & $0.045^{\star \star \star}$ \\
\hline & $(0.005)$ & 0.005 & 0.005 \\
\hline \multirow[t]{2}{*}{ Maths score aged 10 (std.) } & $0.102^{\star \star *}$ & $0.102^{\star \star *}$ & $0.102^{\star \star *}$ \\
\hline & $(0.017)$ & 0.017 & 0.017 \\
\hline \multirow[t]{2}{*}{ Maths score missing } & -0.007 & -0.008 & -0.008 \\
\hline & $(0.037)$ & 0.037 & 0.037 \\
\hline \multirow[t]{2}{*}{ Professional } & $0.254^{\star \star \star}$ & $0.252^{\star \star \star}$ & $0.253^{\star \star \star}$ \\
\hline & $(0.062)$ & 0.063 & 0.063 \\
\hline \multirow[t]{2}{*}{ Managerial-technical } & $0.171^{\star \star *}$ & $0.168^{\star \star \star}$ & 0.169 *** \\
\hline & $(0.040)$ & 0.040 & 0.040 \\
\hline \multirow[t]{2}{*}{ Skilled Non-Manual } & $0.161^{\star \star \star}$ & $0.159^{\star \star \star}$ & $0.159^{\star \star \star}$ \\
\hline & $(0.050)$ & 0.050 & 0.050 \\
\hline \multirow[t]{2}{*}{ Partly Skilled } & $-0.100^{* *}$ & $-0.100^{\star *}$ & $-0.098^{\star \star}$ \\
\hline & $(0.050)$ & 0.050 & 0.050 \\
\hline \multirow[t]{2}{*}{ Unskilled } & -0.075 & -0.073 & -0.072 \\
\hline & $(0.085)$ & 0.085 & 0.085 \\
\hline \multirow[t]{2}{*}{ SEG Missing } & $0.104^{*}$ & $0.104^{*}$ & $0.102^{*}$ \\
\hline & $(0.057)$ & 0.057 & 0.057 \\
\hline \multirow[t]{2}{*}{ Advice } & & & -0.152 \\
\hline & & & 0.357 \\
\hline \multirow[t]{2}{*}{ Help with application form } & & & -0.170 \\
\hline & & & 0.358 \\
\hline \multirow[t]{2}{*}{ Referee } & & & -0.205 \\
\hline & & & 0.364 \\
\hline \multirow{2}{*}{ Recommend to current/former employer } & & & -0.188 \\
\hline & & & 0.361 \\
\hline \multirow[t]{2}{*}{ Recommend to another employer } & & & -0.147 \\
\hline & & & 0.373 \\
\hline \multirow[t]{2}{*}{ Directly employed me } & & & -0.165 \\
\hline & & & 0.360 \\
\hline \multirow[t]{2}{*}{ Helped find job through contacts } & & & -0.207 \\
\hline & & & 0.357 \\
\hline \multicolumn{4}{|l|}{ Financial } \\
\hline \multirow{2}{*}{ Other } & & & -0.326 \\
\hline & & & 0.418 \\
\hline \multicolumn{4}{|l|}{ Parents help type Missing } \\
\hline \multirow{2}{*}{ Receive any parental help } & & 0.023 & -0.124 \\
\hline & & 0.030 & 0.221 \\
\hline \multirow[t]{2}{*}{ Constant } & $7.311^{\star \star \star}$ & $7.299 \star \star \star$ & $7.626^{\star \star \star}$ \\
\hline & $(0.064)$ & 0.066 & 0.424 \\
\hline$n$ & 2966 & 2966 & 2966 \\
\hline R-squared & 0.089 & 0.090 & 0.090 \\
\hline
\end{tabular}

Notes. Standard errors in brackets. ${ }^{* \star},{ }^{* *}$ and * indicate significance at the $1 \%, 5 \%$ and $10 \%$ levels respectively. The excluded category of parental SEG at age 10 is Skilled Manual. 
Table 7. The relationship between parental help and age 42 log gross monthly wages: females

\begin{tabular}{|c|c|c|c|}
\hline & Spec. I & Spec. II & Spec. III \\
\hline \multirow[t]{2}{*}{ Years of education } & $0.059^{\star \star \star}$ & 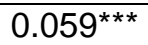 & $0.059^{\star \star \star}$ \\
\hline & $(0.005)$ & 0.005 & 0.005 \\
\hline \multirow{2}{*}{ Maths score aged 10 (std.) } & $0.162^{\star \star \star}$ & $0.162^{\star \star \star}$ & $0.162^{\star \star \star}$ \\
\hline & $(0.018)$ & 0.018 & 0.018 \\
\hline \multirow[t]{2}{*}{ Maths score missing } & 0.037 & 0.038 & 0.038 \\
\hline & $(0.038)$ & 0.038 & 0.038 \\
\hline \multirow[t]{2}{*}{ Professional } & $0.181^{\star \star \star}$ & $0.176^{\star \star}$ & $0.178^{\star \star}$ \\
\hline & $(0.069)$ & 0.070 & 0.070 \\
\hline \multirow[t]{2}{*}{ Managerial-technical } & 0.051 & 0.046 & 0.046 \\
\hline & $(0.040)$ & 0.041 & 0.041 \\
\hline \multirow[t]{2}{*}{ Skilled Non-Manual } & 0.052 & 0.049 & 0.051 \\
\hline & $(0.053)$ & 0.053 & 0.053 \\
\hline \multirow[t]{2}{*}{ Partly Skilled } & -0.063 & -0.061 & -0.058 \\
\hline & $(0.049)$ & 0.049 & 0.049 \\
\hline \multirow[t]{2}{*}{ Unskilled } & -0.084 & -0.082 & -0.088 \\
\hline & $(0.090)$ & 0.090 & 0.090 \\
\hline \multirow[t]{2}{*}{ SEG Missing } & -0.046 & -0.045 & -0.046 \\
\hline & $(0.058)$ & 0.058 & 0.058 \\
\hline \multirow[t]{2}{*}{ Advice } & & & 0.051 \\
\hline & & & 0.597 \\
\hline \multirow[t]{2}{*}{ Help with application form } & & & -0.018 \\
\hline & & & 0.597 \\
\hline \multirow[t]{2}{*}{ Referee } & & & -0.201 \\
\hline & & & 0.606 \\
\hline \multirow[t]{2}{*}{ Recommend to current/former employer } & & & 0.017 \\
\hline & & & 0.600 \\
\hline \multirow[t]{2}{*}{ Recommend to another employer } & & & 0.184 \\
\hline & & & 0.611 \\
\hline \multirow[t]{2}{*}{ Directly employed me } & & & -0.030 \\
\hline & & & 0.601 \\
\hline \multirow[t]{2}{*}{ Helped find job through contacts } & & & 0.026 \\
\hline & & & 0.597 \\
\hline Financial & & & - \\
\hline \multirow[t]{2}{*}{ Other } & & & 0.006 \\
\hline & & & 0.634 \\
\hline \multirow[t]{2}{*}{ Parents help type Missing } & & & 0.264 \\
\hline & & & 0.730 \\
\hline \multirow[t]{2}{*}{ Receive any parental help } & & 0.038 & 0.030 \\
\hline & & 0.030 & 0.218 \\
\hline \multirow[t]{2}{*}{ Constant } & $6.474^{\star \star \star}$ & 6.460 *** & $6.459^{\star \star *}$ \\
\hline & $(0.069)$ & 0.069 & 0.637 \\
\hline $\mathrm{N}$ & 3,187 & 3,187 & 3,187 \\
\hline R-squared & 0.100 & 0.100 & 0.102 \\
\hline
\end{tabular}

Notes. Standard errors in brackets. ***, ${ }^{* *}$ and * indicate significance at the $1 \%, 5 \%$ and $10 \%$ levels respectively. The excluded category of parental SEG at age 10 is Skilled Manual. Financial help contains no observations. 
Table 8 contains the results of a specification using the subjective valuation of parental help documented earlier in Table 5 and considering its association with wages. The table reports results both for men and women and comparison of the two columns of results underlines the comments made above about the different impact of the parental SEG measures and the control variables by gender. The results provide some validation of the subjective valuations and at the same time are consistent with the explanation of the insignificance of the single dummy for parental help of any type in Tables 6 and 7. Parental help that is reported as having contributed 'a lot' to the individual's career or current occupation is associated with an approximately $10 \%$ average wage premium for both men and women, although the coefficients are not that well determined $(\mathrm{t}=2.5$ for men and 2.6 for women). Help that contributed 'not at all' has a negative but insignificant association, while help that contributed 'a little' has a positive but insignificant association. The significant parental SEG coefficients are practically unchanged for men from those in Table 6 - the parental help that contributes 'a lot' or 'a little' does not help explain the association of higher parental occupations with wages.

Table 8. Self-valuation of parental help and its association with age 42 log gross monthly wages

\begin{tabular}{|c|c|c|}
\hline & Male & Female \\
\hline \multirow[t]{2}{*}{ Years of education } & $0.046^{\star \star \star}$ & $0.058^{\star \star \star}$ \\
\hline & (0.005) & $(0.005)$ \\
\hline \multirow[t]{2}{*}{ Maths score aged 10 (std.) } & $0.104^{\star \star \star}$ & $0.164^{\star \star \star}$ \\
\hline & $(0.017)$ & $(0.018)$ \\
\hline \multirow[t]{2}{*}{ Maths score missing } & -0.003 & 0.038 \\
\hline & $(0.037)$ & $(0.038)$ \\
\hline \multirow[t]{2}{*}{ Professional } & $0.252^{\star \star \star}$ & $0.182^{\star \star \star}$ \\
\hline & $(0.063)$ & $(0.069)$ \\
\hline \multirow[t]{2}{*}{ Managerial-technical } & $0.165^{\star \star \star}$ & 0.046 \\
\hline & $(0.040)$ & $(0.041)$ \\
\hline \multirow[t]{2}{*}{ Skilled Non-Manual } & 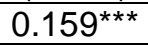 & 0.051 \\
\hline & $(0.050)$ & $(0.053)$ \\
\hline \multirow{2}{*}{ Partly Skilled } & $-0.096^{*}$ & -0.059 \\
\hline & $(0.050)$ & $(0.049)$ \\
\hline \multirow[t]{2}{*}{ Unskilled } & -0.068 & -0.085 \\
\hline & $(0.085)$ & $(0.089)$ \\
\hline \multirow[t]{2}{*}{ SEG Missing } & $0.108^{\star}$ & -0.044 \\
\hline & $(0.057)$ & $(0.058)$ \\
\hline \multirow[t]{2}{*}{ Help contributed a lot } & $0.100^{* *}$ & $0.117^{\star \star \star}$ \\
\hline & $(0.042)$ & $(0.045)$ \\
\hline \multirow[t]{2}{*}{ Help contributed a little } & 0.048 & $0.074^{*}$ \\
\hline & $(0.040)$ & $(0.043)$ \\
\hline \multirow[t]{2}{*}{ Help contributed not at all } & -0.049 & -0.055 \\
\hline & $(0.039)$ & $(0.042)$ \\
\hline \multirow{2}{*}{ Constant } & $7.288^{\star \star \star}$ & $6.465^{\star \star \star}$ \\
\hline & $(0.066)$ & $(0.069)$ \\
\hline $\mathrm{N}$ & 2.966 & 3.187 \\
\hline R-squared & 0.091 & 0.103 \\
\hline
\end{tabular}

Notes. Standard errors in brackets. ***, ** and * indicate significance at the $1 \%, 5 \%$ and $10 \%$ levels respectively. The excluded category of parental SEG at age 10 is Skilled Manual. 
In Tables 9-11 we repeat the exercise for the individual's SEG at age 42 as the outcome of interest. We again use OLS regression despite the ordinal nature of the dependent variable (coding unskilled as 1 through to professional as 6 and dropping cases with missing SEG). Column 1 in Table 9 (men) and Table 10 (women) contains the parental SEG variables but no controls - the result here measure all direct and indirect association of parental and offspring SEG, just as the in the transition matrix reported earlier in Table 5 . In column 2 we add the education and ability variables, in column 3 the single parental help variable, and then adding additional type of help variables in column 4 . Table 11 is the analogue of Table 8, with results for both men and women of a model with three dummy variables for subjective valuation of any help received.

The results suggest a strong relationship between parental SEG and the cohort member's own SEG for both men and women. Much of this correlation is explained by the fact that higher parental SEG is associated with the cohort member having more education and higher levels of ability. However, once these factors are controlled in the model, a strong relationship between parental SEG and an individual's SEG at age 42 persists, particularly for men. This strong link between parental SEG and own SEG is therefore not entirely explained by higher levels of education and ability. We then explore whether parental assistance can explain this strong relationship. However, just as in the wage models above, we find that individuals who report receiving help from their parents do not achieve higher occupational status in the labour market at age 42. The use of parental support does not therefore explain the strong residual relationship we observe between parental and own SEG.

In contrast to the results for wages, for men there is no indication in Table 11 that the individual's subjective valuation that help received has contributed 'a lot' to the SEG attained at age 42, indeed the estimated coefficient is negative albeit insignificant. But for women the same pattern is found of help that is reported as important being associated with a statistically increase in the value of the outcome variable $(t=2.5)$, controlling for other factors. The estimated coefficient (0.142) may seem modest in size when viewed against the range of the dependent variable ( 1 to 6 ) but is similar in magnitude to that on the dummy variable for a parent age 10 in the managerial-technical group. 
Table 9. The relationship between parental help and age 42 SEG: males

\begin{tabular}{|c|c|c|c|c|}
\hline & Spec. $V$ & Spec. VI & Spec. VII & Spec. VIII \\
\hline \multirow[t]{2}{*}{ Years of education } & & $0.121^{\star \star \star}$ & $0.121^{\star \star \star}$ & $0.121^{\star \star \star}$ \\
\hline & & $(0.006)$ & $(0.006)$ & $(0.006)$ \\
\hline \multirow[t]{2}{*}{ Maths score aged 10 (std.) } & & $0.258^{\star \star \star}$ & $0.259^{\star \star \star}$ & $0.256^{\star \star \star}$ \\
\hline & & $(0.024)$ & $(0.024)$ & $(0.024)$ \\
\hline \multirow[t]{2}{*}{ Maths score missing } & & -0.032 & -0.032 & -0.035 \\
\hline & & $(0.045)$ & $(0.045)$ & $(0.045)$ \\
\hline \multirow[t]{2}{*}{ Professional } & $0.955^{\star \star \star}$ & $0.460^{\star \star \star}$ & $0.462^{\star \star \star}$ & $0.451^{\star \star \star}$ \\
\hline & $(0.083)$ & $(0.080)$ & $(0.080)$ & $(0.080)$ \\
\hline \multirow[t]{2}{*}{ Managerial-technical } & $0.540^{* \star *}$ & $0.299^{\star \star * *}$ & $0.302^{\star * *}$ & $0.300 * \star *$ \\
\hline & (0.051) & $(0.048)$ & $(0.048)$ & $(0.048)$ \\
\hline \multirow[t]{2}{*}{ Skilled Non-Manual } & $0.483^{\star \star \star}$ & $0.296^{\star \star \star}$ & $0.298^{\star \star \star}$ & $0.296^{\star \star \star}$ \\
\hline & $(0.066)$ & $(0.062)$ & $(0.062)$ & $(0.062)$ \\
\hline \multirow[t]{2}{*}{ Partly Skilled } & $-0.119^{*}$ & -0.067 & -0.068 & -0.065 \\
\hline & $(0.066)$ & (0.061) & (0.061) & (0.061) \\
\hline \multirow[t]{2}{*}{ Unskilled } & $-0.369 * \star \star$ & $-0.263^{\star *}$ & $-0.264^{\star *}$ & $-0.260^{* *}$ \\
\hline & $(0.114)$ & (0.106) & $(0.106)$ & $(0.106)$ \\
\hline \multirow[t]{2}{*}{ SEG Missing } & $0.156^{\star \star}$ & 0.095 & 0.095 & 0.090 \\
\hline & $(0.073)$ & $(0.068)$ & $(0.068)$ & $(0.068)$ \\
\hline \multirow[t]{2}{*}{ Advice } & & & & 0.040 \\
\hline & & & & $(0.165)$ \\
\hline \multirow[t]{2}{*}{ Help with application form } & & & & -0.042 \\
\hline & & & & $(0.168)$ \\
\hline \multirow[t]{2}{*}{ Referee } & & & & 0.087 \\
\hline & & & & $(0.184)$ \\
\hline \multirow[t]{2}{*}{ Recommend to current/former employer } & & & & -0.107 \\
\hline & & & & $(0.175)$ \\
\hline \multirow[t]{2}{*}{ Recommend to another employer } & & & & -0.176 \\
\hline & & & & $(0.198)$ \\
\hline \multirow[t]{2}{*}{ Directly employed me } & & & & 0.089 \\
\hline & & & & $(0.170)$ \\
\hline \multirow[t]{2}{*}{ Helped find job through contacts } & & & & -0.164 \\
\hline & & & & $(0.164)$ \\
\hline \multirow[t]{2}{*}{ Financial } & & & & $0.567^{\star}$ \\
\hline & & & & $(0.335)$ \\
\hline \multirow[t]{2}{*}{ Other } & & & & -0.053 \\
\hline & & & & $(0.271)$ \\
\hline \multirow[t]{2}{*}{ Parents help type Missing } & & & & $-1.646^{*}$ \\
\hline & & & & $(0.990)$ \\
\hline \multirow[t]{2}{*}{ Receive any parental help } & & & -0.024 & -0.034 \\
\hline & & & $(0.036)$ & $(0.249)$ \\
\hline \multirow[t]{2}{*}{ Constant } & $3.865^{\star \star \star}$ & $2.497^{\star \star \star}$ & $2.510^{\star * *}$ & $2.562^{\star \star \star}$ \\
\hline & $(0.032)$ & $(0.078)$ & $(0.081)$ & $(0.282)$ \\
\hline $\mathrm{N}$ & 3,890 & 3.877 & 3,877 & 3,877 \\
\hline R-squared & 0.070 & 0.199 & 0.199 & 0.205 \\
\hline
\end{tabular}

Notes. Standard errors in brackets. ***, ** and * indicate significance at the $1 \%, 5 \%$ and $10 \%$ levels respectively. The excluded category of parental SEG at age 10 is Skilled Manual. 
Table 10. The relationship between parental help and age 42 SEG: females

\begin{tabular}{|c|c|c|c|c|}
\hline & Spec. $V$ & Spec. VI & Spec. VII & Spec. VIII \\
\hline \multirow[t]{2}{*}{ Years of education } & & $0.093^{\star \star \star}$ & $0.093^{\star \star \star}$ & $0.092^{\star \star \star}$ \\
\hline & & $(0.007)$ & $(0.007)$ & $(0.007)$ \\
\hline \multirow[t]{2}{*}{ Maths score aged 10 (std.) } & & $0.255^{\star \star \star}$ & $0.255^{\star \star \star}$ & $0.253^{\star \star \star}$ \\
\hline & & $(0.025)$ & $(0.025)$ & $(0.025)$ \\
\hline \multirow[t]{2}{*}{ Maths score missing } & & -0.011 & -0.011 & -0.008 \\
\hline & & $(0.048)$ & $(0.048)$ & $(0.048)$ \\
\hline \multirow[t]{2}{*}{ Professional } & $0.727^{* \star *}$ & $0.315^{\star \star *}$ & $0.309 * \star *$ & $0.301^{\star \star *}$ \\
\hline & $\begin{array}{l}(0.087) \\
\end{array}$ & $(0.086)$ & $(0.086)$ & $(0.086)$ \\
\hline \multirow[t]{2}{*}{ Managerial-technical } & $0.380^{\star \star \star}$ & $0.147^{\star \star \star}$ & 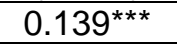 & $0.132^{\star \star \star}$ \\
\hline & $(0.051)$ & $(0.050)$ & $(0.051)$ & $(0.051)$ \\
\hline \multirow[t]{2}{*}{ Skilled Non-Manual } & $0.201^{* \star *}$ & 0.067 & 0.062 & 0.052 \\
\hline & $(0.069)$ & $(0.067)$ & $(0.067)$ & $(0.067)$ \\
\hline \multirow[t]{2}{*}{ Partly Skilled } & -0.089 & -0.063 & -0.062 & -0.060 \\
\hline & $(0.065)$ & $(0.062)$ & $(0.062)$ & $(0.062)$ \\
\hline \multirow[t]{2}{*}{ Unskilled } & $-0.257^{\star *}$ & -0.108 & -0.103 & -0.097 \\
\hline & $(0.116)$ & $(0.111)$ & $(0.111)$ & $(0.111)$ \\
\hline \multirow{2}{*}{ SEG Missing } & -0.107 & $-0.137^{\star}$ & $-0.134^{*}$ & $-0.137^{\star}$ \\
\hline & $(0.075)$ & $(0.072)$ & $(0.072)$ & $(0.072)$ \\
\hline \multirow[t]{2}{*}{ Advice } & & & & -0.275 \\
\hline & & & & (0.573) \\
\hline \multirow[t]{2}{*}{ Help with application form } & & & & -0.219 \\
\hline & & & & $(0.574)$ \\
\hline \multirow[t]{2}{*}{ Referee } & & & & -0.527 \\
\hline & & & & $(0.588)$ \\
\hline \multirow[t]{2}{*}{ Recommend to current/former employer } & & & & -0.430 \\
\hline & & & & $(0.579)$ \\
\hline \multirow[t]{2}{*}{ Recommend to another employer } & & & & -0.155 \\
\hline & & & & $(0.597)$ \\
\hline \multirow[t]{2}{*}{ Directly employed me } & & & & -0.252 \\
\hline & & & & $(0.579)$ \\
\hline \multirow[t]{2}{*}{ Helped find job through contacts } & & & & -0.432 \\
\hline & & & & $(0.575)$ \\
\hline Financial & & & & - \\
\hline \multirow{2}{*}{ Other } & & & & -0.583 \\
\hline & & & & $(0.632)$ \\
\hline \multirow[t]{2}{*}{ Parents help type Missing } & & & & -0.829 \\
\hline & & & & $(0.809)$ \\
\hline \multirow[t]{2}{*}{ Receive any parental help } & & & 0.055 & -0.212 \\
\hline & & & $(0.038)$ & $(0.271)$ \\
\hline \multirow[t]{2}{*}{ Constant } & $3.979 * \star \star$ & $2.951^{\star \star \star}$ & $2.930^{\star \star \star}$ & $3.522^{\star \star \star}$ \\
\hline & $(0.032)$ & $(0.085)$ & $(0.087)$ & $(0.638)$ \\
\hline $\mathrm{n}$ & 3,767 & 3,759 & 3,759 & 3,759 \\
\hline R-squared & 0.039 & 0.126 & 0.127 & 0.130 \\
\hline
\end{tabular}

Notes. Standard errors in brackets. ***, ** and * indicate significance at the $1 \%, 5 \%$ and $10 \%$ levels respectively. The excluded category of parental SEG at age 10 is Skilled Manual. Financial help contains no observations. 
Table 11. Self-valuation of parental help and its association with age 42 SEG

\begin{tabular}{|l|c|c|}
\hline & Male & Female \\
\hline Years of education & $0.120^{\star \star \star}$ & $0.093^{\star \star \star}$ \\
\hline & 0.006 & 0.007 \\
\hline Maths score aged 10 (std.) & $0.257^{\star \star \star}$ & $0.256^{\star \star \star}$ \\
\hline & 0.024 & 0.025 \\
\hline Maths score missing & -0.030 & -0.012 \\
\hline & 0.045 & 0.048 \\
\hline Professional & $0.458^{\star \star \star}$ & $0.311^{\star \star \star}$ \\
\hline & 0.080 & 0.086 \\
\hline Managerial-technical & $0.301^{\star \star \star}$ & $0.138^{\star \star \star}$ \\
\hline & 0.048 & 0.051 \\
\hline Skilled Non-Manual & $0.296^{\star \star \star}$ & 0.065 \\
\hline & 0.062 & 0.067 \\
\hline Partly Skilled & -0.072 & -0.060 \\
\hline & 0.061 & 0.062 \\
\hline Unskilled & $-0.263^{\star \star}$ & -0.105 \\
\hline & 0.106 & 0.111 \\
\hline SEG Missing & 0.096 & $-0.137^{\star}$ \\
\hline & 0.068 & 0.072 \\
\hline Help contributed a lot & -0.057 & $0.142^{\star \star}$ \\
\hline & 0.050 & 0.056 \\
\hline Help contributed a little & 0.035 & 0.066 \\
\hline & 0.050 & 0.054 \\
\hline Help contributed not at all & -0.024 & -0.024 \\
\hline & 0.048 & 0.052 \\
\hline Constant & $2.513^{\star \star \star}$ & $2.930^{\star \star \star}$ \\
\hline & 0.081 & 0.087 \\
\hline & & \\
\hline $\mathrm{n}$ & 3,877 & 3,759 \\
\hline R-squared & 0.200 & 0.128 \\
\hline & & \\
\hline
\end{tabular}

Notes. Standard errors in brackets. ${ }^{* *},{ }^{* *}$ and * indicate significance at the $1 \%, 5 \%$ and $10 \%$ levels respectively. The excluded category of parental SEG at age 10 is Skilled Manual.

\section{Conclusions}

In this paper we have produced new evidence from the 1970 British Birth Cohort Study on the prevalence of help in the job market from parents, other relatives and friends. In doing so we have also reported new estimates of the extent of social mobility in Britain today, specifically on the strong association between parental socio-economic group when cohort members were aged 10 and their own socio-economic group and earnings aged 42. Our findings are stark: a person's socio-economic background continues to have a persistent and large impact on their eventual occupation and earnings. Much of this impact is via the effect of parental SEG on an individual's ability and education. However, beyond that it remains true for this cohort that parental SEG is strongly associated with own SEG, even after allowing for the impact of family background on ability and education. Intra-generational social mobility continues to be constrained in England.

We then considered an important route by which parental SEG might influence an individual's labour market success, namely through the use of networks and specifically assistance in the labour market from parents. Reported help in the job market is widespread 
- about a half of the cohort report help from parents and about a half report help from parents and friends. Advice is easily the most widely reported type of help, especially from parents, but a substantial proportion of respondents report that parents helped them find a job through their contacts ( $29 \%$ of men and $21 \%$ of women) or that other relatives or friends helped in this way ( $25 \%$ of men and $16 \%$ of women). Recommendation to a current or former employer is also quite widely reported.

Parental help has a clear social gradient, being more common for individuals with parents from higher socio-economic groups and higher levels of family incomes, while help from other relatives and friends has little association with family socio-economic background. However, it is help in the form of advice and assistance with applications forms that drives this social gradient of parental help. Help from parents in the form of recommendation to a current or former employer or in finding a job through their contacts has little apparent relationship with parental socio-economic status.

Our results indicate that individuals who report receiving help from their parents do not have higher earnings than those who do not receive such help, nor do they have higher status occupations. It would seem therefore that parental help is not necessarily beneficial in the labour market and certainly parental help cannot explain the very strong relationship between parental SEG and own SEG. One might imagine this is because some help is more beneficial than others. About a third of people receiving parental help report that they believe it contributed a lot to their career or current occupation. Individuals who report receiving help from their parents that contributed a lot to their career do appear to have significantly higher wages at age 42, controlling for other factors. This is the case for both men and women but only for women could we also find an association of parental help of this type with the individual's occupation (defined in broad categories) at age 42. For both genders and for both wages and occupations, help viewed by the respondent as having made no contribution to their career or occupation was confirmed as having no association with their wage or broad occupation. The implication here is that not all help is valuable but where help is perceived as having value by the cohort member (CM), the $\mathrm{CM}$ is more likely to have higher earnings.

In conclusion, we were unable to identify a clear causal link between any particular type of help - advice, help through contacts etc. - and cohort members' wages or occupations. This implies that other factors and mechanisms must explain the strong intergenerational relationship between parent and CM wages and occupational status. This is an important finding, given that the work also highlights the persistent strong relationship between parental occupation and the CM's own occupation, particularly for males. It is striking that the role of parental SEG in predicting future labour market success is far stronger for males and also goes beyond an impact from parental SEG on the CM's ability and education. Future work could therefore usefully be focused on two features of this literature. First, we need to develop better measures of the extent to which a parent is supporting their child in school and in the labour market. Indeed measurement error in the measures of help may well explain the insignificant relationship between help and wages, if the error is classical. Second, we might consider alternative explanations for the link between parental SEG and own SEG and, on the basis of the findings here, we might also usefully explore differences in the way that parental SEG impacts on men and women's eventual labour market success. 


\section{References}

Bingley, P., Corak, M., \& Westergård-Nielsen, N. (2011) 'The Intergenerational Transmission of Employers in Canada and Denmark'. IZA Discussion Paper No. 5593

Blanden, J., \& Machin, S. (2004) 'Educational Inequality and the Expansion of UK Higher Education'. Scottish Journal of Political Economy, 51, 230-249.

Blanden, J., Goodman, A., Gregg, P., \& Machin, S. (2004) 'Changes in intergenerational mobility in Britain', in Corak, M. (ed) Generational Income Mobility in North America and Europe. Cambridge University Press, Cambridge.

Blanden, J., Gregg, P., \& Macmillan, L. (2013) 'Intergenerational Persistence in Income and Social Class: The Impact of Within-Group Inequality'. Journal of Royal Statistical Society Series A: Statistics in Society, 176 (2), 541-563.

Bukodi, E., \& Goldthorpe, J. H. (2011) 'Social Class Returns to Higher Education: Chances of Access to the Professional and Managerial Salariat for Men in Three British Birth Cohorts'. Longitudinal and Life Course Studies, vol 2, 1-71.

Cabinet Office (2009) 'Unleashing Aspirations: The Final Report of the Panel on Fair Access to the Professions'. London: Information Policy Team.

Cabinet Office (2011) 'Opening Doors, Breaking Barriers: A Strategy for Social Mobility'. London: Information Policy Team.

Cabinet Office (2012) 'Fair Access to Professional Careers: A Progress Report by the Independent Reviewer on Social Mobility and Child Poverty'. London: Information Policy Team.

Coleman, J. S. (1990) 'Foundations of Social Theory'. Cambridge, MA: Harvard University Press.

Corak, M., \& Piraino, P. (2010) 'The Intergenerational Transmission of Employers'. IZA Discussion Paper No. 4819

Erikson, R., \& Goldthorpe, J. (2010) 'Has social mobility in Britain decreased? Reconciling divergent findings on income and class mobility'. British Journal of Sociology, 61, 211-230.

Ermisch, J., Jantti, M., \& Smeeding., T. (2012) The Intergenerational Transmissions of Advantage, New York: Russell Sage Foundation.

Fernandez, R. M., \& Castilla, E. J. (2001) 'How much is that network worth? Social capital in employee referral networks'. Social Capital: Theory and Research, 85-104.

Goldthorpe, J. (2013) 'Understanding - and Misunderstanding - Social Mobility in Britain: The Entry of the Economists, the Confusion of Politicians and the Limits of Educational Policy'. Journal of Social Policy, 42 (3), 431-450.

Goldthorpe, J., \& Mills, C. (2008) 'Trends in intergenerational class mobility in modern Britain: Evidence from National Surveys, 1972-2005'. National Institute Economic Review, 205, 83-100.

Gorard, S. (2008) 'A Re-consideration of Rates of Social Mobility in Britain: Or Why Research Impact is not Always a Good Thing'. British Journal of Sociology of Education 29, 317-24.

Haveman, R., \& Wolfe, B. (1995) 'The Determinants of Children's Attainments: A Review of Methods and Findings'. Journal of Economic Literature, 33(4), 1829-78.

Holzer, H. J. (1988)' Search Method Use by Unemployed Youth'. Journal of Labour Economics, Vol. 6(1), 1-20.

Ioannides, Y., \& Loury, L. (2004) 'Job information networks, neighbourhood effects and inequality'. Journal of Economic Literature, Vol. 42(4). pp. 1056-1093 
Kramarz, F., \& Skans, O. (2006) 'Nepotism at work? Family networks and youth labour market entry'. Unpublished manuscript, Symposium of Labor Economics (ESSLE).

Langlands, A. (2005) The Gateways to the Professions Report ('The Langlands Report'). Nottingham: DfES.

Loury, G. C. (1977) A Dynamic Theory of Racial Income Differences, in Women, Minorities and Employment Discrimination. PA Wallace and A. Le Mund, eds. Lexington, MA: Lexington Books, Ch. 8.

Loury, L. (2006) 'Some Contacts are More Equal Than Others: Informal Networks, Job Tenure, and Wages'. Journal of Labor Economics, 24 (2), 299-318.

Marsden, P. \& Gorman, E. (2001) Social Networks, Job Changes, and Recruitment, in Sourcebook of Labor Markets: Evolving Structure and Processes. Ivar Berg and Ame L. Kalleberg, eds. New York: Kluwer Academic/Plenum Publishers, pp. 467-502.

Macmillan, L. (2009) Social Mobility and the Professions. Centre for Market and Public Organisation.

Macmillan, L., Tyler, C., \& Vignoles. A. (2013) 'Who gets the Top Jobs? The role of family background and networks in recent graduates' access to high status professions' DoQSS Working Paper 13-15, Institute of Education, London.

Sutton Trust (2005) The Educational Background of the UK's Top Solicitors, Barristers and Judges.

Sutton Trust (2006) The Educational Backgrounds of Leading Journalists. 